\title{
PRÁTICAS DE FABRICAÇÃO: HIGIENE E SUJEIRAS NA PRODUÇÃO DE PÃES E PADEIROS
}

\author{
Antônio de Salvo Carriço ${ }^{1}$ \\ ${ }^{1}$ Universidade Federal do Rio de Janeiro (UFRJ), Museu Nacional, Programa \\ de Pós-graduação em Antropologia Social, Rio de Janeiro, RJ, Brasil
}

\section{Introdução}

Este artigo aborda a relação entre discursos técnicos, construções simbólicas e práticas sociais, problematizando suas fronteiras aparentes e analisando as articulações pelas quais se constituem efetivamente. Esta discussão é mobilizada pela questão da higiene como instituição normativa, que conjuga uma proclamação objetivista e de cunho impessoal com relações de poder entre sujeitos localizados. O objeto empírico a partir do qual analiso essas questões se encontra na produção e na venda de pães: mais especificamente, parto de uma comparação entre as condições de higiene encontradas em dois contextos nos quais me envolvi diretamente durante minhas trajetórias de pesquisa - como aluno matriculado em um curso de formação de padeiros do Serviço Nacional de Aprendizagem Industrial (Senai ${ }^{1}$ ) e como funcionário de padarias comerciais. Uma primeira vista oferece uma comparação simples e evidente: são contextos opostos no que se refere à limpeza. O Senai possui instalações que primam pelo asseio, enquanto as padarias fazem jus à fama de locais não exatamente asseados. Argumento, porém, que ambos podem ser entendidos a partir de dinâmicas semelhantes, se não a mesma dinâmica, em relação à higiene, se questionarmos sua "naturalidade" e analisarmos as dinâmicas pelas quais determinados discursos e práticas a elas relacionados se atualizam.

Trata-se, afinal, de um artigo baseado em pesquisas etnográficas que se compreendem dentro de uma linha antropológica de produção de conhecimento - as aulas no Senai foram meu objeto de estudo no mestrado em Antropologia (Carriço, 2011), enquanto as experiências que tive trabalhando como padeiro e balconista fizeram parte da pesquisa de doutorado (Carriço, 
2016a). Deste modo, ao lidar com limpeza, sujeira e higiene, não posso deixar de remeter aos aportes fundamentais de Mary Douglas (1966) e levar em consideração que estas nunca são ideias ou práticas que podem ser compreendidas em si mesmas. Pelo contrário, elas só fazem sentido se relacionadas a sistemas específicos em função dos quais são concebidas como poluição e adquirem um caráter potencial de perigo - danos fisiológicos que podem ser causados a um ser humano, mas sobretudo um perigo relativo a uma ordem social e simbólica como um todo.

Ao abordar comparativamente a higiene em um curso de formação de padeiros e em padarias comerciais, não tenho como objetivo apresentar um quadro quantitativamente verificável de bactérias, coliformes ou outras ameaças que sequer reconheço. Muito pelo contrário, o que proponho neste texto é justamente explorar e desenvolver algumas relações que constituem a premissa, colocada por Douglas, segundo qual a "desordem" só faz sentido se pensada a partir de uma "ordem", tanto como consequência de algo que não se adequa a um conjunto de relações quanto como motivação e parte constitutiva do próprio processo de ordenação. Na medida em que essa ordem deve ser compreendida sobretudo em suas bases culturais e sociais, examiná-la pode se revelar uma entrada fértil para a compreensão de processos e dinâmicas como as analisadas neste artigo.

Partindo, portanto, dos processos de produção de pães e de padeiros em que me inseri como pesquisador "participante", argumento neste artigo ser possível, e de certa forma necessário, considerar a "higiene" segundo uma lógica de apropriação específica, enfatizando as dinâmicas sociais particulares em função das quais é mobilizado seu caráter de objetividade, cientificidade e impessoalidade. ${ }^{2}$ É importante destacar que os sujeitos que ponho em cena são padeiros, balconistas, professores, alunos ou clientes: sujeitos "comuns", trabalhadores oriundos de classes populares, donos de padarias que dividem o abastecimento de pequenos bairros, professores com experiência como padeiros, mas sem formação universitária aprofundada, que conduzem aulas para pequenas turmas em um país que não prima pelos investimentos na educação, mesmo quando supostamente atrelada ao mercado de trabalho. Não são cientistas, por um lado, dentro ou fora de seus laboratórios, e também não são instituições ou agentes dotados legal ou politicamente de qualquer autoridade para impor uma visão a outros. Ainda assim, são sujeitos de alguma maneira afetados por uma forma de discurso "científico", capazes de identificar certos conceitos e relações e de se apropriarem criativamente desse conhecimento e de sua aura de factualidade em suas interações cotidianas. ${ }^{3}$

Embora a argumentação tenha início com um exercício de relativização da sujeira em cada um dos casos, não é este, simplesmente, o objetivo final, 
assim como passa longe de minhas intenções insistir em ou reforçar separações entre ciência e cultura, crença e prática, conhecimento e ação. Pelo contrário, ao trazer interações cotidianas entre sujeitos específicos, o que busco é trabalhar justamente nas articulações pelas quais essas dimensões se atualizam: trata-se de analisá-las em ato, em processo, refletindo sobre a natureza dessas articulações, pois é somente aí que cada uma delas ganha sentido. Por outro lado, se enfatizo semelhanças encontradas em ambos os contextos, mais que as diferenças gritantes entre eles, talvez seja por operar, de certa forma e em escala reduzida, o que Appadurai (2008) propõe como uma «história social» da higiene (mais que do próprio pão, neste caso), acompanhando-a em suas transformações do Senai às padarias comerciais, junto à minha própria trajetória de pesquisa.

\section{Sobre as pesquisas que baseiam este artigo}

É importante, antes de mais nada, esclarecer para o leitor de onde partem os dados aqui descritos, especialmente a forma como se deu minha inserção nesses contextos. Mencionei que frequentei um curso de formação de padeiros no Senai (além de outros mais curtos, como fabricação de pizzas, panetones e doces para confeitaria), e que trabalhei em algumas padarias durante a pesquisa da tese. Em ambos os casos, "fazer-me nativo" e inserir-me como aluno e funcionário para compreender os processos em questão foi uma abordagem adotada como resposta a condições e dificuldades impostas pelo próprio campo.

No primeiro caso, uma alternativa a uma série de recusas que me dificultavam o acesso à indústria de alimentos, de modo geral: meu projeto original envolvia o estudo de redes de fast-food ou franquias similares que lidassem com a produção e a venda de gêneros alimentícios. Com o prazo se aproximando, adotei essa estratégia de me matricular em um curso de seis meses de duração que era ofertado pelo Senai em um bairro próximo à minha residência, no Rio de Janeiro. ${ }^{4}$ Pagando mensalidades e sujeitando-me ao lugar de aluno, ao invés de procurar a direção e apresentar minhas intenções de pesquisa (que não escondi, durante as aulas), encontrei uma forma de me inserir no campo da alimentação, ainda que estivesse fazendo uma curva em relação ao plano original, saindo do trabalho propriamente dito para um ambiente "escolar".

Inspirado na obra de Loïc Wacquant (2002) sobre o aprendizado do boxe, busquei aproveitar ao máximo esse lugar de aluno e investir analiticamente nos processos de aprendizagem que se davam a partir da interação 
entre alunos e professores naquele contexto tão particular de qualificação profissional. Procurei deter-me não apenas em um conteúdo entendido como pronto e reproduzível, mas como algo que se construía e era apropriado de formas não previstas também nas conversas paralelas, nas fofocas, piadas e intrigas entre os sujeitos envolvidos. Ao submeter-me eu mesmo ao processo, pude investir ainda na sensibilização técnica envolvida em fazer pães, no desenvolvimento de sentidos específicos em relação à massa (tato, olfato, paladar, audição...) e às agências próprias das substâncias envolvidas.

Terminado o curso e o mestrado, e tendo em mãos meu diploma de "Padeiro" emitido pelo Senai, decidi seguir os passos de Simone Weil (1979), Robert Linhart (1980) e Donald Roy (1953), autores que se puseram em contato direto com o trabalho no "chão de fábrica" para compreendê-lo sociologicamente e/ou influenciá-lo politicamente. Empregar-me em uma padaria, no entanto, foi muito mais difícil do que eu imaginava, contrastando de forma aguda com o discurso oficial promovido pelo Senai e divulgado em jornais e na televisão sobre a "empregabilidade garantida" pela "qualificação": "só fica desempregado se quiser muito", cheguei a ouvir de um diretor do Senai em uma palestra. Não apenas o meu certificado não me garantia uma vaga, como ele parecia dificultar ainda mais a situação, reificando a estranheza que minha condição pouco usual provocava - explicitar as intenções de pesquisa tampouco me trazia benefícios, neste sentido. Essa barreira encontrada me fez voltar as atenções para o balcão e os balconistas, que marcavam a lógica espacial desses estabelecimentos e, ao contrário do que acontecia com os padeiros, "escondidos" no interior da padaria, desenvolviam (parte de) suas atividades em público, lidando com clientes. A partir daí, compreender e explorar analiticamente uma rotatividade muito grande encontrada naquela função e suas implicações para as configurações hierárquicas desenvolvidas naquelas padarias passariam a ser o eixo principal da tese (ver Carriço 2016b). De toda forma, em função dessa aproximação com alguns balconistas, consegui enfim alcançar meu objetivo inicial, embora já na fase final da pesquisa, tendo a oportunidade de trabalhar tanto como balconista quanto como padeiro em duas padarias entre o final de 2014 e o início de 2015.

Essas experiências, intensas e ricas em si mesmas, se tornavam ainda mais interessantes quando contrastadas ao ambiente que encontrava no Senai. Não demorou para entender boa parte dos receios de gerentes em relação à formação que se tem naqueles cursos, uma vez que a passagem de um contexto de ensino em uma instituição especializada para o de uma padaria comercial não é de forma alguma linear, constituindo muito mais um corte que uma progressão, em vários sentidos. Esses contrastes são 
reconhecidos pelas pessoas vinculadas a ambos os lados, embora sejam significados de formas específicas, e ocupam um lugar fundamental na forma como cada contexto se compreende em relação ao outro (ver Carriço, no prelo). Um desses contrastes se refere às técnicas corporais mobilizadas, as próprias sensibilidades em relação à massa que desenvolvi na dissertação: da calma à pressa, da sutileza e leveza nas mãos à força nos braços, cotovelos e pernas; outro, relacionado àquele, diz respeito à higiene, como veremos.

\section{Pães que o diabo amassou}

O imaginário sobre padarias e padeiros tem pelo menos dois lugares comuns: por um lado, a visão de que o trabalho em padarias é particularmente duro, e do padeiro, consequentemente, como alguém que se submete, dia após dia, a extensas, ingratas e sucessivas jornadas de trabalho madrugada adentro, tudo para garantir que o "pão nosso de cada dia" esteja disponível para venda a cada manhã; por outro lado, uma ideia de que o processo de produção se desenvolve com um certo desleixo em relação à higiene e à assepsia de substâncias, instrumentos e corpos: que o pão é produzido em meio a ratos e baratas, detritos corporais (o suor do padeiro é o de menos, nesses casos), cinzas de cigarro e fuligem, um ambiente que se mistura à massa e se camufla no produto final. De fato, a julgar pelo modo como as padarias aparecem na literatura sociológica, esse imaginário tem bases materiais bastante apuradas.

O pão assume destaque, por exemplo, na análise de Thompson (1998) sobre as revoltas populares na Inglaterra no contexto que antecede a revolução industrial, especialmente por sua capacidade de "ocultar" ingredientes e substâncias misturadas durante o preparo. Marx, por sua vez, dedica algumas páginas de seu O Capital ao drama dos padeiros, no contexto da discussão sobre uma lei destinada a evitar a adulteração de alimentos e bebidas:

De qualquer modo, o comitê conduziu a atenção do público para seu pão quotidiano e, com isso, para a panificação. Ao mesmo tempo, ressoou em comícios e em petições dirigidas ao Parlamento a reclamação dos empregados das padarias contra o trabalho em excesso etc. A reclamação assumiu tal força que foi nomeado comissário real do inquérito H. S. Tremenheere [...] Seu relatório, junto com os depoimentos das testemunhas, revolveu não o coração, mas o estômago do povo. O inglês, versado na Bíblia, sabia que o ser humano, que não foi predestinado para ser capitalista, senhor das terras ou sinecurista, está 
condenado a comer o pão com o suor de seu rosto, mas não sabia que tinha de comer diariamente, com o pão, certa quantidade de suor humano misturado com supurações de abscessos, teias de aranhas, baratas mortas e fermento podre alemão, além de alúmen, saibro e outros ingredientes minerais agradáveis. Por isso, sem qualquer consideração pelo "comércio livre", a panificação até então "livre" ficou submetida à fiscalização de inspetores do Estado [...] e pela mesma lei que estabelecia essa providência, ficou proibido aos empregados de padaria menores de 18 anos trabalharem de 9 da noite às 5 da manhã. A lei põe em evidência o trabalho em excesso nesse ramo comercial tão antigo e tradicional (Marx 2006:289-290).

Um salto temporal e geográfico nos mostra uma situação parecida no Brasil contemporâneo, como indicam as manchetes a seguir, todas datadas de 2017: "Padaria é fechada por falta de higiene e risco à saúde"; "Vigilância Sanitária interdita padaria em Sorocaba cheia de baratas e equipamentos"; "Vigilância acha insetos mortos e produtos vencidos em padaria de $\mathrm{RO}^{\prime} ;{ }^{7}$ "Operação encontra farinha com fezes de rato em padaria na Gávea"; "Padaria é interditada por ter rato, baratas e alimentos vencidos, em Goiânia - Dono foi preso em flagrante. Cerca de $340 \mathrm{~kg}$ de produtos impróprios para consumo foram recolhidos". ${ }^{9}$

Não é de se espantar, portanto, que um curso como o do Senai, ao propor um processo de qualificação que se pauta em muitos sentidos por uma distinção entre o "certo" e o "errado", se dedique com afinco sobre ambos os aspectos daquele imaginário que mencionei. Por um lado, os ritmos específicos do curso em relação às urgências cotidianas de uma padaria e sua dinâmica própria de funcionamento conformam um contexto de trocas discursivas e elaborações simbólicas que incentiva a explicitação e o combate a condições de trabalho que representem uma exploração além do que se considera justo; ${ }^{10}$ por outro, existe uma preocupação muito grande com as chamadas "Boas Práticas de Fabricação", uma noção que tem suas origens nas Good Manufacturing Practices elaboradas pela indústria farmacêutica dos Estados Unidos na década de 60 e consolidadas e difundidas pela Organização Mundial da Saúde a partir da década seguinte. Trata-se de normas e recomendações que abarcam e promovem uma organização "racional" da produção, enfatizando sobretudo a higiene do processo como um todo, seja de instrumentos, práticas, costumes, produtos ou pessoas envolvidas. O ensino das Boas Práticas ocupa um espaço importante da formação no Senai, que trata essa preocupação com a higiene como uma das principais características e um dos grandes "diferenciais" do profissional "qualificado" por seus cursos. 
Essas recomendações são em via de regra apresentadas por agências e empresas sob a forma de algo já pronto e (muito bem) acabado: apoiadas por uma aparente cientificidade garantida por números exatos, termos técnicos e unidades de medida precisas, que funcionam como um efeito de objetividade, elas são dadas a conhecer como um consenso científico. ${ }^{11}$ A tônica é a da normatividade, e não há espaço para dúvida, para discussão, para uma problematização que ameace avançar um pouco mais no questionamento e abalar suas bases. Como nos mostra Latour (1993, 1994, 2001; Latour \& Woolgar 1997), porém, tais consensos escondem uma série de controvérsias e embates em torno de definições e de legitimidade entre pesquisadores de diversas áreas, e estão em constante tensão. Seria equivocado, no entanto, simplificar o argumento destes autores e limitar tais dinâmicas a um momento determinado, conformando uma distinção entre o que ocorreria dentro de um mundo científico, que seria vivo e dinâmico, e o que ocorreria para além dele, onde o produto dessas dinâmicas se encontraria pronto e estável. Para o desenvolvimento do argumento aqui proposto me parece importante considerar determinados sentidos em que, mesmo depois que a "caixa de Pandora" é fechada, esse conhecimento, aparentemente "estabilizado", segue latente. Afinal, ainda que normas de higiene sejam introduzidas aos alunos como um "fato", é possível se perguntar pela "vida" que elas adquirem em uma sala de aula, pelas peculiaridades das relações e dinâmicas nas quais se inserem e que, como tema, também introduzem. Nesse sentido, observaremos a seguir o decorrer de uma aula sobre assunto durante o curso que acompanhei no Senai.

\section{Aprendendo a ter nojo}

"Antônio, vem aqui pra frente... vamos fazer uma encenação. Você vai lavar as mãos. Roberta, você vai ser a torneira. Vamos ver como se lavam as mãos". Bastante constrangido, me dirijo à frente da sala; Roberta inclina os braços para cima, simulando as torneiras da pia. Giro sua mão esquerda e começo a esfregar minhas mãos uma na outra.

"O que vocês acham?", pergunta André - o professor - à turma, que não vê maiores problemas. "Tem uma coisa errada ali: ele tinha que esfregar mais entre os dedos, ali se concentram muitos micro-organismos, e isso passa para o que vocês estiverem produzindo. Por isso é bom também sempre passar um álcool depois". Repetimos a encenação, e desta vez procuro enfatizar toda a superfície das mãos. Roberta levanta o outro braço para que possa "aplicar" o álcool em gel. 
Vocês, como manipuladores de alimentos, têm que prestar muita atenção com a higiene, têm que tomar muito cuidado. Os micro-organismos são transmitidos de várias formas: pelo ar, por pragas ou animas, higienização deficiente, pela água, por embalagens ou armazenamento mal feitos... mas principalmente pelo homem. Porque a gente tem manias, às vezes traz de casa alguns hábitos que não são adequados. Passar a mão no cabelo ou outras partes do corpo: o que adianta lavar as mãos por 10 minutos se assim que termina você ajeita o penteado? Ou então o pão caiu no chão, aí dá aquela assoprada nojenta e acha que tá tudo bem?

“Mas é possível manter o alimento completamente limpo?", pergunta Leandro.

Boa pergunta. É sempre possível ocorrer contaminação. Na verdade, todo alimento está contaminado, o que vai fazer mal ou não é a quantidade de micro-organismos se reproduzindo ali. Existem técnicas pra manter o alimento seguro, nós vamos ver daqui a pouco, esses dias. Tem que ver a temperatura, porque existe uma temperatura ideal pra proliferação desses micro-organismos, a higienização correta dos equipamentos... Um setor de produção bem planejado, cada coisa em seu lugar. Mas é conjunto: infraestrutura, recebimento dos produtos, armazenamento, onde vai guardar farinha, onde vai guardar ovo, açúcar, margarina... Tem o preparo do pessoal, a informação que eles têm... Se falhar um, vai tudo mal. Por isso a importância do treinamento pra despertar a consciência. Eu vou passar depois pra vocês a RDC 216, da Anvisa, que regula todas essas questões de boas práticas.

A conversa segue, e Jorge argumenta que "é questão de educação também, né, professor? Se faz errado em casa, vai pro trabalho e faz igual". André concorda: "E são coisas simples também. Tomar banho todo dia, cabelo limpo, penteado, não usar anel, brinco, maquiagem, perfume... escovar os dentes, lavar as mãos, uniformes limpos... Tudo muito óbvio, mas você sai por aí e vê cada coisa que vou te contar. É de dar nojo!".

"Pois é, professor, é verdade", comenta Karina: "eu trabalhei numa lanchonete no Flamengo que tinha um cidadão lá que juro por Deus, ele fedia! Simplesmente ele não tomava banho, sabe? E chegou num ponto que era difícil ficar perto dele! Então a gente pegou ele um dia ele e teve que dar um banho na marra!". "Não tô falando?", responde o professor, em meio a risos incrédulos.

André coloca um vídeo instrutivo sobre boas práticas de fabricação e higiene. Além de se deter nos aspectos já mencionados, o vídeo nos traz uma série de "prejuízos" decorrentes da contaminação de alimentos, associando a higiene a consequências drásticas: surtos, epidemias, mortes; desperdício de alimento; fiscalização, multas e indenizações, demissão de 
funcionários; reclamações, queda de reputação, perda da clientela, falência e fechamento. O vídeo prossegue em tom de ameaça: "Como ficaria a sua consciência se metade dos seus clientes passasse mal depois de comer no seu estabelecimento? E se fossem trabalhadores de uma fábrica, que não pudessem trabalhar?".

"Mas com tudo isso, por que não faz certo?", brada uma indignada Karina, apoiada por Jorge e Lídia. "Não entendo isso...". André passa então a citar exemplos que presenciou:

Mas você vê, o que a gente vê por aí... Descuido, despreparo... Uma vez eu entrei numa padaria onde me sai um infeliz de bermuda e chinelo, todo sujo. Eu virei pra atendente e perguntei: "Vem cá... Quem é ele?". Ela virou e disse: "O padeiro". "Então suspende o pão". Outra vez disseram pra não me preocupar, que "ele não é padeiro, é só ajudante". Não dá, né? Vocês não vão mais conseguir entrar em padarias, e não só por saber fazer pão. Depois que sabemos o certo, não conseguimos fazer errado... aí você vê esse tipo de coisa. Já bati de frente com muito dono de padaria por isso... E mercado? Trabalhando em mercado a gente vê cada coisa nojenta... eu sempre dizia pra todo mundo pra ficar longe, não comprar lá.

Karina comenta que é um absurdo e uma falta de respeito com o cliente, e André continua a narrar episódios repugnantes:

Claro! Gente, se você parar pra pensar e observar as coisas que acontecem... Vocês vão ver quando saírem daqui... O perigo que é comer na rua. Eu tava com a minha irmã e minha sobrinha saindo do cinema e parei numa barraquinha dessas de cachorro-quente. Tinha só uma pessoa vendendo, preparando tudo e recebendo o dinheiro. Elas pediram os delas e eu lá só vendo. A mulher com aquele dinheiro entre os dedos, pegando salsicha, molho, batata... e dava o cachorro-quente, pegava o dinheiro com a mão, e continuava a fazer outro assim, na maior tranquilidade. Na hora que ela montou o meu e foi me dar, eu falei "não, não quero não". Aí começa: "Por que não?". Eu disse que a mão dela tava suja, aquelas notas eram imundas... Aí vem a minha irmã falar que eu sou chato, fresco... Mas eu tô certo, quem tava errada era a dona do cachorro-quente! Se ela quisesse comer, problema dela, eu falei, "aqui eu não como". Agora eu passo por lá e a mulher me olha com cara feia... Mas é inevitável. Vocês vão olhar de cima a baixo, ver os gestos, a higiene, os cuidados...

"E isso porque você tá ali na frente dela vendo, né? Imagina o que não fazem quando não tem ninguém vendo?", provoca Beto. É o mote para mais histórias de André: 
E quando o funcionário acha que vai prejudicar o patrão? O que eu já ouvi de história de você ficar com medo mesmo de comer por aí... Eu já soube de um cara que trabalhava numa lanchonete dessas grandes aí, e um dia tava chegando a hora de ir embora e um gerente desses puxa-saco da empresa resolveu que todo mundo ia fazer hora extra pra lavar o chão, arrumar estoque, essas coisas. Quando o gerente saiu, né, os funcionários já p. da vida com ele, fizeram um esquema: ficou um olhando se ele voltava, enquanto o outro abriu aqueles recipientes onde ficam os sucos, sabe? Esses refrescos? Ele abriu e urinou ali! É um idiota, acha que com isso vai prejudicar o patrão, mas quem vai se ferrar é ele! Além de botar muita gente em risco.

"Como é que pode, tem que demitir um imbecil desse, mandar prender! Que absurdo!". Karina mal pode se conter, mas André continua: E pior que essas coisas não são só pra ilustrar a aula não, isso acontece mesmo! Eu falo aqui e as pessoas acham que é mentirinha, historinha do André... É que tem gente muito tapada mesmo! Eu conheci um cara que simplesmente.... é, bom... como é que eu vou explicar... é... ele tava "por aqui" com o dono da padaria, né, e digamos... o cara depositou sua carga genética na massa.

É o estopim para uma série de reações indignadas e enojadas, apenas contidas pelo intervalo.

A preocupação com a higiene da produção é algo que se procura inculcar durante o curso, e essa inculcação se dá marcadamente através de trocas de anedotas como as descritas: experiências e histórias que narram situações em que cuidados tidos como básicos não foram observados. Seu propósito, ao serem contadas, é a produção ou a explicitação de um sentimento de nojo, que aparece como única reação legítima diante dos fatos.

Esse contraste entre o certo e o errado, o que se deveria fazer e o que é feito, o limpo e o sujo se impõe como tema de conversas em vários momentos de um curso de formação, mas é especialmente relevante quando os alunos têm alguma oportunidade de experimentar a "vida lá fora". Foi o caso, por exemplo, de uma aluna desta turma, que abandonou um "estágio" que havia conseguido em uma padaria de seu bairro por conta das condições sanitárias que encontrou, reforçando o que havia sido ensinado no Senai: "Aquele chiqueiro... Cara, a gente sempre comprava pão lá, agora eu já falei pra minha mãe, já proibi ela de comprar qualquer coisa lá".

Minha própria passagem do curso para o trabalho em padarias se deu apenas quatro anos depois, quando já não fazia parte desse contexto de conversas, mas carregou com ela muitas daquelas expectativas e critérios de como seria uma padaria ideal em termos de limpeza. Não tardou, dessa 
forma, para que eu percebesse algumas diferenças em relação ao ambiente "pasteurizado" do curso: as masseiras, as divisoras, os armários e os utensílios impecáveis davam lugar a crostas de um uso acumulado; a "geladeira", um grande frigorífico que deveria auxiliar no armazenamento de produtos e no prolongamento de sua utilidade, não era o ambiente mais agradável ou limpo da padaria - um certo aroma de substâncias velhas ou em vias de decomposição dava um toque característico ao local. Algumas concentrações de algo marrom se distribuíam pelo teto e pelas bordas da estante - talvez ferrugem ou algo do tipo - dais quais se precipitavam algumas gotas que teimavam em escorrer pelo meu braço quando precisava buscar algo no local. Era ali que se guardavam cremes, ovos e massas cruas de pão, e nem sempre era possível mantê-los devidamente protegidos.

Por fim, algo que havia marcado minha passagem pelo Senai e que dificilmente poderia ser reproduzido por escrito, pois remetia ao domínio sensorial do olfato: uma mistura peculiar - interpreto como farinha, aditivos, gemas, margarina e açúcar - que impregnava o ambiente com um aroma distintivo. Reencontrei esse aroma ao adentrar a padaria como funcionário; seu aspecto agradável, porém, era desafiado por outros aromas que não faziam parte do cotidiano controlado do Senai: dezenas de frangos não tão frescos empilhados em um tanque, o cheiro vindo do banheiro, seja pelo que se fazia lá dentro (fumar, por exemplo, além das necessidades fisiológicas), seja pela quantidade de produtos de limpeza que ali se aplicavam, ou os próprios odores corporais, inevitáveis diante do calor do forno e do esforço exigido pelo ritmo da produção.

Pouco se comentava a esse respeito por parte dos funcionários da padaria - gerentes, balconistas, padeiros ou confeiteiros - com duas notáveis exceções: eu mesmo, aquela peculiar combinação entre novato ${ }^{12}$ egresso do Senai e etnógrafo, e Adilson, um mecânico externo ao quadro de funcionários regulares da padaria, chamado quando necessário para consertos e manutenção das máquinas utilizadas na produção. Nós nos conhecemos quando ele apareceu para consertar uma geladeira. Montado sobre ela, Adilson buscava entender o problema do regulador de temperatura. "Você é novato, né? Já tá aprendendo isso aqui também?", ele me pergunta, jogando lá de cima pedaços de queijo e potinhos com temperos. Apenas rio e digo que não tenho nada com isso. Ele segue retirando aparelhos e substâncias do seu caminho. Um ralador de queijo, alguns sacos plásticos de conteúdo já difícil de identificar... Até que encontra, enfim, a causa do problema. "Olha isso!", me diz, com algo na mão. É um gravetinho quebrado. Um pedaço de palha, talvez? "Como é que isso veio parar aqui? Isso é um pedaço do cesto! Tava preso na hélice do exaustor! Aí travou tudo, claro...". 
Adilson mostra a outros funcionários, mas ninguém tem uma explicação plausível para aquilo - apenas demonstram espanto, e colocam na conta dos padeiros da manhã, aqueles "porcos" e "malucos": "tem que dar uma dura neles", alguém diz.

Não me surpreendo ao constatar, no dia seguinte, que tudo aquilo que fora retirado de cima da geladeira estava novamente ali, com exceção do pedaço do cesto. Adilson também não parecia surpreso e, ao retornar para consertar os comandos e o visor, começou a preparar uma barreira para impedir que fossem colocadas coisas indevidas naquele lugar. Desta vez estávamos acompanhados pelo principal gerente da padaria, Seu Jairo. "Agora ninguém vai mais jogar nada aqui", diz Adilson. Ele interrompe a instalação da placa e me pede a espátula que usamos para auxiliar no preparo da massa. Ele raspa com força a parte superior da geladeira, provocando uma chuva de detritos. "Cara, isso é cheio de bactéria... é nojento, por que fazem isso?". O patrão está na minha frente, apenas sorrio em concordância. Seu Jairo demonstra indignação com seus padeiros, que não estão ali: "e não é por falta de disposição! Por que não falam comigo isso? A gente dá todas as condições, vê o que precisa, dá um jeito!".

Escutar de membros importantes da padaria este tipo de afirmação me causava certo desconforto. Seu Jairo sabia melhor do que ninguém que seus funcionários dispunham de uma liberdade grande para realizar as tarefas, e que restringir essas apropriações improvisadas do espaço significaria engessar a dinâmica de funcionamento da padaria. Ou por acaso teria se esquecido que nunca me dera instrução alguma, por exemplo, simplesmente jogando para os demais funcionários a tarefa de me apresentar à padaria? Da mesma forma, me parecia cínica a denúncia de alguns funcionários sobre o estado de padarias concorrentes - histórias envolvendo ratos, gatos, guimbas de cigarro, lâminas e práticas semelhantes às narradas nas aulas do Senai. Eles sabiam muito melhor do que eu, afinal, das baratas que volta e meia passeavam pelas assadeiras e carrinhos e que vez ou outra encontravam seu destino no calor do forno. Ou do estado das assadeiras, que seguiam em uso mesmo com grandes amassados e rachaduras pontiagudas. O que dizer então dos acúmulos de ferrugem na geladeira, ou daqueles salgados resfriados visivelmente vencidos, mas que seguiam sendo assados e servidos, nunca retirados de circulação? Ou dos cestos de pães descobertos envelhecendo ao lado e em cima do forno, antes de virarem farinha de rosca? Talvez os anos de convívio com o forte cheiro das dezenas de frangos não exatamente frescos tenham afetado sua percepção das coisas... ou talvez a questão seja mais complexa, afinal. 


\section{Sujeiras como sistemas}

Se tomarmos a higiene como um dado, um padrão objetivamente mensurável a partir do qual se comparam diferentes objetos, locais ou produtos, veremos, nessa comparação proposta entre a oficina do Senai e as padarias comerciais, diferenças gritantes. Bastaria observar o estado das masseiras, das assadeiras, dos armários e dos próprios pães para encerrar a discussão e constatar o óbvio: que são níveis distintos de assepsia, e que seria preciso uma intensa e constante limpeza nas padarias para que se equiparassem ao ambiente controlado do curso. Contudo, conforme indiquei anteriormente, meu argumento é de que ambos podem também ser equiparados e compreendidos pelas semelhanças que apresentam, que fundamentalmente ambos mobilizam as mesmas dinâmicas em relação à higiene. Por que insistir nisso quando é evidente que, do ponto de vista sanitário, existe um abismo entre os dois contextos?

Para seguir a argumentação, recupero aqui o trabalho de Mary Douglas (1966) a partir da ideia da higiene (e da poluição, mais adiante), que aparece como um aspecto relevante para se compreenderem as dinâmicas de tabu e as atitudes em relação a elas. Se a noção de um "medo fundamental" que povoaria a mente e o corpo de certos grupos ou pessoas diante de proibições parece pouco válida empiricamente e não permite que se entendam a fundo as questões envolvidas, como argumenta a autora, o conceito de sujeira (dirt) apareceria como um eixo mais produtivo, ao permitir considerá-las sob um ponto de vista mais amplo, e não apenas como atributos de povos supostamente "primitivos". Dessa forma, sua análise, focada na simbologia judaico-cristã, visa compreender processos simbólicos presentes em qualquer sociedade, independentemente de seu suposto grau de desenvolvimento. A noção de um sistema simbólico de classificação é fundamental aqui: seja confinando certas práticas como tabu, seja denunciando algo como "sujo" ou "impuro", é essencialmente um desafio à classificação que se coloca, para a autora, e é diante desse desafio que emergem teorias nativas sobre perigo, danos e malefícios.

Pensar a sujeira como um mecanismo fundamental da classificação social, nesse sentido, implica considerá-la a partir de uma ótica particular: a de que a sujeira, como tal, não existe. Nada - nenhum objeto, prática ou substância - é sujo por si só, a não ser que esteja relacionado a um sistema de classificação que assim o compreenda - uma forma de organizar ou conceber a realidade em que determinado item não se encaixe adequadamente, apresentando-se contraditório, ambíguo ou dissonante. Por um lado, esta abordagem traz a sujeira como uma categoria universal de entendimento: 
não há contexto possível em que uma ideia de sujeira não seja verificável e, mais do que isso, ofensiva. Por outro, é preciso ter em conta que essa categoria universal não possui um conteúdo predeterminado - o que é ou não considerado sujeira depende de maneira inescapável das classificações em uso em contextos específicos.

A premissa de que se deve considerar a sujeira dentro de estruturas mais amplas de significação pede que se estabeleça quais seriam, em cada caso, essas referências estruturais relevantes. Afinal, essa premissa permite trabalhar em diversas escalas, desde uma cosmologia ocidental moderna, de forma geral, até uma análise de dinâmicas entre pais e filhos em relação à arrumação de uma cama, por exemplo. Se cabe também ao pesquisador determinar as relações relevantes para a compreensão de seu objeto, então creio que se possa pensar produtivamente em cada um desses contextos - a padaria e o Senai - de início, como contextos que conformam maneiras específicas de conceber e lidar com sujeira, e que devem, assim, ter suas dinâmicas compreendidas como se fossem de fato isoláveis. ${ }^{13}$ Creio que este seja um ponto de partida interessante para iniciar o diálogo com algumas das ideias de Douglas. A partir daí, poderemos aprofundar, mais adiante, a análise.

\section{Sujeiras em uma padaria comercial, da produção à venda}

Para pensarmos no contexto de uma padaria comercial, sugiro que retornemos, de início, ao caso envolvendo Adilson, o técnico que, montado sobre a geladeira, encontrava e denunciava uma série de produtos que ali estavam. Deixemos de lado, por ora, o aspecto de denúncia do episódio, ao qual retornaremos em breve, e nos concentremos no caráter cotidiano do uso daquele espaço e dos objetos: queijos, temperos e outros produtos dispostos sobre uma máquina, ao alto. Um queijo colocado - ou mesmo esquecido - em cima de um armário, por exemplo, não parece ser considerado, no fluxo cotidiano daquela padaria, como "lixo" ou um elemento de "contaminação". Ele apenas "está ali": não apresenta nenhum inconveniente e não exige qualquer tipo de mobilização - a não ser que um graveto prejudique o funcionamento daquela geladeira. Da mesma forma, a parte externa da masseira, que torna visíveis as toneladas de massa que já foram produzidas ali, não é propriamente suja, nesta concepção - diferente seria, talvez, se a parte interna estivesse em semelhante estado.

Não posso dizer que me empenhava ao máximo para deixar as assadeiras impecáveis. De tão desgastadas pelo tempo, era difícil para mim, por 
vezes, distinguir o que era sujeira do que era parte integrante do material, de tão embrenhados que estavam. Ainda assim, esfregava-as com esponja e detergente de modo a retirar ao menos o que havia de mais explícito - o que me parecia o "excesso", pode-se dizer - e nunca ouvi uma reclamação a esse respeito. Por outro lado, se eu deixasse um pedaço de pão doce grudado no meio de uma forma, certamente isto seria notado. Teriam de interromper o ritmo para, no mínimo, colocá-la novamente junto à pilha de instrumentos sujos, o que acontecia com certa frequência com as assadeiras de pão francês, que eram simplesmente deixadas de lado até que algum de nós as esfregasse com uma escova de aço para livrá-las dos restos de pães grudados. Não se falava em sujeira, enfim, se ela não estivesse de fato impedindo ou ao menos dificultando o fluxo da produção.

Isto não significa que se desconheça aquela concepção impessoal e universalizante de "higiene", tampouco que esta lógica interna seja a única operante no cotidiano da padaria: trata-se de lógicas que coexistem e que se atravessam em situações específicas. Prova desse diálogo é que o trato com o cliente se baseia não nas urgências e nas classificações próprias da produção, mas naqueles mesmos princípios de assepsia que povoam o discurso mais abstrato e normativo das "boas práticas": o uso de luvas e pinças no balcão, a restrição ao contato direto do produto pelos balconistas, o descarte do produto que vai ao chão... Se observarmos os atos dos balconistas, veremos que eles não tocam diretamente no produto ao servi-lo. Eles usam pinças e luvas para servir pães, bolos, biscoitos, frios ou qualquer outra coisa. Uma questão de higiene, se apressariam a dizer gerentes ou gestores das "boas práticas da produção". Mais sincera, uma balconista que me ensinava a trabalhar no setor já me alertava que "não é bom que o cliente veja a gente botando a mão nas coisas".

Trata-se de uma espécie de inversão, tornada complementar, da dinâmica de produção neste tipo de padaria, que é perpassada pelo contato direto das substâncias e produtos com o corpo do trabalhador. Ainda que se disponha de masseiras, cilindros, divisoras e modeladoras, máquinas que, em teoria, se incumbem do preparo da massa, desde a mistura e sova dos ingredientes, passando pela divisão em porções finais e na modelagem característica da maioria dos pães, são as mãos de padeiros e balconistas os braços como um todo, no caso da passagem da massa pelo cilindro, que depende de uma técnica corporal bastante desenvolvida pelo padeiro - que transportam toda a produção de um instrumento a outro, complementam a função da modeladora e acomodam os pães prontos em bandejas e embalagens plásticas. Fazem jus, enfim, à expressão popular "botar a mão na massa". Passada aquela porta que separa a produção da exposição dos produtos para 
venda, porém, a mão humana torna-se tabu, foco de contágio e poluição, devendo permanecer distante dos produtos que tanto devem a elas.

A figura do cliente é fundamental aqui: fora de seu alcance, a mão humana deixa de ser um fator de contaminação. A mesma balconista que protege os produtos de seu corpo através do uso de luvas de plástico, pinças e espátulas ao servir no balcão, toca à vontade em qualquer produto no interior da padaria, sem nenhuma preocupação com a suposta assepsia promovida pelos frios instrumentos exibidos do lado de fora. Em meio a assadeiras velhas, carrinhos enferrujados e eventuais insetos ou roedores, suas mãos são provavelmente uma das coisas mais "limpas" pelas quais o pão passou, mas isso não vem ao caso: a higiene é muito mais algo a ser exibido do que algo de fato mensurável e perseguido internamente na produção.

Assim, um pão que caia no chão do lado de dentro da padaria, esteja ele cru ou assado, é colocado de volta em seu lugar, sem qualquer separação entre ele e os demais, como se nada tivesse acontecido. No balcão, por outro lado, um pão caído é rapidamente pego com as mãos - ele já não é mais apresentável, e o uso das mãos deixa isto o mais explícito possível - e é posto de lado para ser jogado no lixo... ou ao menos é a impressão que se quer passar para quem possa ter presenciado o ocorrido: na primeira oportunidade, este pão é levado para dentro e colocado de volta no cesto (se estiver muito danificado pela queda, é jogado em uma das caixas de pães velhos, ao lado do forno, para um dia virar farinha de rosca), de onde voltará para a venda como um "novo" e "fresco" pão. O cliente não sabe o que se passa do outro lado daquela porta, e é possível jogar com isso de acordo com as lógicas e as urgências próprias da produção.

Não é, portanto, que não haja de fato uma preocupação e um esforço em manter o local limpo e bem organizado - é evidente que há. Mas o que se percebe aí são diferentes sujeiras que se concebem durante seus tratos cotidianos: classificações distintas que se revelam em relação às múltiplas lógicas de interação postas em prática da produção à venda.

\section{Sujeiras no Senai: técnica, distinção e qualificação}

Se as concepções de sujeira e limpeza em uma padaria podem ser relacionadas a cadências de produção características, é de se esperar que o ambiente do curso, marcado por uma relação com o trabalho que se dá fora de suas urgências cotidianas, apresente concepções bastante diferentes a este respeito. Dessa forma, alunos e professores são constantemente orientados a lavar as mãos antes de iniciar as atividades na oficina, a manter a 
touca sempre bem posicionada, a utilizar roupas brancas limpas e a manter a barba feita - todas estas práticas comuns também na padaria, mas que não são cobradas com a mesma intensidade. Ainda que os próprios alunos limpem mesas, instrumentos e máquinas ao final das aulas, existem funcionários responsáveis exclusivamente pela faxina das instalações, e deve-se muito a eles o estado geral do local. Nas padarias que pesquisei, são os balconistas que fazem a limpeza cotidiana, dividindo ou acumulando suas atenções e energias entre atividades como recolher o lixo, limpar o banheiro, a máquina de assar frangos, servir café e sanduíches aos clientes e sair para fazer entregas - o que necessariamente implica um cálculo particular de prioridades no qual eventuais normas e convenções de higiene frequentemente são deixadas em segundo plano diante da pressão de gerentes, das demandas de clientes e do horário de encerramento do expediente.

Para compreender o lugar da higiene nesse contexto, no entanto, é preciso notar que, diferentemente do silêncio tácito que encontrei na padaria, no Senai esta é uma categoria discursiva importante. É um tema frequente de conversas e aulas, na medida em que se apresenta como uma das bases da legitimação da ideia da qualificação e de um profissional que se distingue dos demais. Se o curso pode ser visto como um ritual, um grande rito de passagem de pessoas a padeiros ou de padeiros comuns a padeiros qualificados, é importante encarar aquelas anedotas como espécies de mitos, evocações que sugerem um determinado estado de coisas e indicam uma configuração em que os personagens e as ações trabalham em meio a significados em transformação.

É interessante observar, nesse sentido, o movimento que conduz para um polo comum, naquelas conversas que se estruturam em função do ensino da higiene, as preocupações de patrões, funcionários e consumidores. A obsessão pela higiene, colocada como ciência através do apoio da biologia, é trazida como um fato técnico e objetivo, um ideal necessariamente benéfico e indispensável a todos os envolvidos, não importa sua posição. É constitutivo do curso, em seu caráter de mediação entre pessoas, trabalhadores e patrões, estabelecer uma base comum e racionalmente determinada de entendimento e inquietações: um padeiro de verdade, diferenciado, deve guiar-se por essas prerrogativas, e não por "manias" e "atalhos" que acabam se revelando traiçoeiros. E é através de uma concepção de técnica, ciência e objetividade que está além de aspectos sociais que se opera, de início, essa abstração. Ao lidar com a normatização de práticas de trabalho (e de vida, no limite), o curso se apoia, nesse sentido, em concepções de sujeira e limpeza entendidas como absolutas, como coisas verificáveis, quantificáveis e que devem ser eliminadas ou perseguidas. Daí o nojo em relação às condições 
encontradas em outras padarias, que provém justamente de uma recusa a se admitir a relatividade da sujeira - ou da dificuldade de lidar com essa possibilidade dentro de um conteúdo programático oficial pautado por uma gestão racional e científica da vida social. ${ }^{14}$

\section{Categorias em ação}

Ao considerar sujeira e limpeza como concepções simbólicas inseridas em contextos de significação específicos, podemos compreender melhor a que se referem e como contribuem para organizar estes mesmos contextos. Devemos admitir, contudo, que seguimos distantes daquela semelhança fundamental que apresentei no início: o Senai e a padaria seguem diferentes, apenas relativizados. Se isso revela, por um lado, uma semelhança de natureza entre contextos diferentes, por outro os torna ainda mais diferentes entre si. As semelhanças aparecem, de fato, quando colocamos esses esquemas na prática, em movimento, não como lógicas abstratas, apenas, mas como lógicas de ação, mobilizadas por agentes dentro de relações e interações particulares.

Uma forma simples de iluminar a questão é, mantendo-se no Senai, sair das aulas teóricas para as aulas práticas: como toda a energia dispensada a este tópico em sala de aula se manifestava na oficina? Em que pesem as reações fervorosas mencionadas anteriormente sobre a falta de higiene na produção de alimentos, não parecia haver uma preocupação extrema com a higiene pela higiene em si mesma. Sim, a limpeza de todas as mesas era checada pela manhã e ao final do expediente; limpávamos cuidadosamente assadeiras e masseiras antes e depois do uso, e cuidávamos para que nossas roupas permanecessem brancas ao longo do dia. Creio, porém, que todo esse zelo é mais bem compreendido em função da construção de um valor do trabalho em oposição à preguiça do que por qualquer complicação "puramente higiênica". Cheguei a discutir em uma ocasião por um pedaço de massa devolvido do chão à assadeira, algo não tão incomum na ausência de professores por perto ("não vai jogar fora não, foda-se que caiu no chão, o pão é meu, eu faço o que quiser com ele. Se não quiser não come"). Presenciei inclusive um professor ingerindo um pão de queijo que havia caído da bandeja para baixo de uma mesa: "o que não mata engorda, assoprou tá limpo!". No entanto, vi-me frequentemente acusado de "preguiça" ou "corpo mole" no que se refere à limpeza dos equipamentos.

Para além de fatores "puramente biológicos" - ou a partir do se entende por "puramente biológico" - a higiene pode ser inserida em uma complexa 
rede de acusações e provocações jocosas entre alunos e professores. "Cadê a touca do Roberto [faxineiro]?"; "Já lavou a mão, Beto?"; "Olha a mesa suja ali, não vai limpar não?"; "Ei, a touca tem que cobrir a orelha!"; "Que barba é essa aí, já tem que fazer de novo!"; "Vai deixar a forma suja assim?"; "Pode entrar com a blusa estampada que nem a dele, professor?"; "A outra turma fuma lá fora e entra na oficina fedendo a cigarro!". Convertida em controle do outro, pelo outro e de si mesmo e relacionada a um valor particular de trabalho, a higiene é mote para todo um processo aparentemente paradoxal de reconfiguração do controle sofrido em potenciais exercícios de controle: a submissão à hierarquia e à ciência das boas práticas de fabricação estabelece as bases para um jogo constante entre pessoas que, cientes das regras que as coagem, extraem delas os mecanismos para sua própria defesa, particularmente através da acusação. ${ }^{15}$

Voltemos, como instrumento de comparação, ao contexto das padarias em que trabalhei, e uma vez mais ao episódio envolvendo o mecânico e o gerente. Em primeiro lugar, ao enunciarem e reprovarem as práticas "erradas" atribuídas aos padeiros do turno da manhã, ambos explicitavam algo que todos conheciam bem, embora muitas vezes tacitamente: que a padaria funciona por conta dos próprios funcionários, que reinventam seu espaço e aproveitam instrumentos de maneiras diversas (muitas vezes se arriscando no calor do forno e colocando em segundo plano a própria segurança em troca da velocidade de execução das tarefas). Ao mesmo tempo, porém, a situação tem um interesse particular para o tema desta discussão. Ao confrontar o gerente sobre a falta de higiene da padaria, Adilson quebrou um silêncio tácito - um tabu, pode-se dizer - sobre a questão.

Adilson é um caso à parte no leque de personagens que compõem o cotidiano da padaria. Parte do dia a dia de vários estabelecimentos, ele não está exatamente imbricado por suas urgências da mesma forma que aqueles que trabalham em apenas um. Ele entra e sai, e com isso consegue participar daquele contexto sem afogar-se em sua lógica própria de funcionamento. Também não está submetido da mesma forma às relações de dominação e força que afetam balconistas, padeiros, confeiteiros, cozinheiros e gerentes, o que não significa que não esteja vinculado de maneira alguma. Nesse sentido, sua posição guarda semelhanças com a minha, a de um etnógrafo que busca imbuir-se da dinâmica social interna da produção ao mesmo tempo em que é capaz de (ou que necessita) distanciar-se dela para objetivar um conhecimento a seu respeito.

Por motivos diferentes, oriundos de trajetórias distintas, estamos, eu e ele, inseridos na produção de maneiras peculiares. Apesar de trabalharmos ali, não temos completamente incorporada (ou mesmo naturalizada) aquela 
urgência cotidiana do funcionamento de uma padaria que se atualiza nas apropriações improvisadas do espaço e das relações entre aquelas pessoas. Assim como eu de certa maneira forçava outros funcionários a discutir questões que não apareciam tão explicitadas normalmente (por exemplo, ao reclamar do cansaço oriundo de quase 15 dias seguidos de trabalho) ${ }^{16}$, Adilson colocava-se também como um foco de perturbações não previstas e levantava questões que apenas um "estrangeiro" pensaria em levantar impunemente.

Analisar aquela cena a partir da noção da quebra de um tabu é interessante porque permite colocar em foco uma série de práticas e relações que conformam o cotidiano da padaria, mas que podem ser produtivamente expandidas a outros contextos. A primeira constatação é a obviedade do que foi dito: que a padaria estava longe de se enquadrar em um padrão ideal de higiene, em termos absolutos, todos sabiam. A relatividade desse padrão, porém, e a primazia das urgências e dos ritmos característicos do funcionamento da padaria são as normas pelas quais se estabelecem as concepções de sujo e limpo e os limites aceitáveis dentro dessas dinâmicas particulares. Isto produz uma espécie de paradoxo: por um lado, não se poderia "discordar" da importância da higiene, entendida como práticas e padrões impessoais, objetivos e universais de assepsia, por outro, é preciso pautar-se por condições possíveis que permitam o funcionamento da padaria tal como negociado ${ }^{17}$ pelos sujeitos que lhe dão corpo, e esta é a base segundo a qual se pautam as decisões, os improvisos e os fazeres cotidianos dessas pessoas. Quebrar o silêncio que se estabelece a respeito da incompatibilidade lógica entre esses dois padrões significa colocar em destaque - e em questão - não apenas a limpeza daquilo que se produz, mas as bases sociais daquela negociação entre sujeitos que dita o ritmo da padaria e engendra uma série particular de possibilidades de significação.

É fundamental, neste ponto, ampliar a ideia de "sujeiras" trabalhada até aqui para articulá-la ao conceito de "poluição" proposto por Mary Douglas (1966, 1968), pois apenas assim poderemos passar de uma noção relativamente estática (a sujeira está na geladeira, a masseira está suja, a mão humana não é limpa) para um conceito que enfatiza a agência em potencial daquilo (ou daquele) considerado sujo ou impuro. A sujeira é perigosa, nesse sentido, porque ela não se contém em si mesma, colocando em risco, por contágio, todo um estado de coisas. Ao configurar-se analiticamente como poluição, substantivo que se refere antes a um movimento que a um objeto, a sujeira ameaça e mobiliza esforços, regras, e fronteiras ao mesmo tempo físicas, simbólicas e morais em relação a uma determinada configuração social. Nesse sentido, ao tratar do conceito de poluição, é preciso considerar que não é a sujeira em si, corporificada na crosta de bactérias ou nas 
baratas sobre os pães, o foco do problema. Talvez se possa concluir que a poluição, no caso aqui em questão, refere-se muito mais às ambiguidades e às contradições explicitadas pelo mecânico, que introduzem dissonâncias que, se não abafadas de alguma maneira, teriam o potencial, no limite, de deslegitimar e abalar toda a configuração laboral da padaria.

Com efeito, ao apontar a sujeira - em seu aspecto objetivado da crosta de bactérias - para o patrão, mas sobretudo ao formular uma pergunta quase retórica acompanhada por um juízo de valor ("é nojento, por que fazem isso?"), Adilson provoca uma situação peculiarmente tensa. Estamos nós três: o (d)enunciador, o patrão e o novato. Embora fosse eu o elo frágil, meu sorriso desconfortável indicava que, estando há poucos dias na padaria e sendo isto do conhecimento de todos, não poderia ser colocado como a fonte do problema, cuja demanda por resposta recaía unicamente sobre Seu Jairo, o patrão. Daí o constrangimento da situação, o desconforto gerado pela impossibilidade de se justificar legitimamente através da lógica da produção sem explicitar as bases - históricas, sociais e políticas envolvendo relações de trabalho, produção e assimetrias entre sujeitos - nas quais ela se desenvolve e em função da qual existe e faz sentido. Não é à toa que Douglas destaca o caráter potencialmente perturbador daquilo que não se adequa a um conjunto estabelecido de relações, bem como todo o esforço ritual empreendido para abafar essa inadequação.

A reação do próprio gerente aparece como contraponto - também retórico - a uma pergunta que não deve ser encarada a sério. Ao articular a denúncia pelo viés da indignação e da surpresa, colocando-se também como vítima e assumindo o ponto de vista proposto por Adilson, Jairo evita um confronto simbólico direto e abafa a ambiguidade e o potencial de perigo que uma resposta pairando no ar pode conter. Afinal, colocar a culpa nos padeiros do turno da manhã permite um fechamento ritual ao diálogo e sobretudo um alívio ao desconforto que a situação produzira. É uma explicação conveniente: se normas ampla e evidentemente legítimas e reconhecidas de higiene não estão sendo seguidas, é porque existem pessoas que não estão se comportando como deveriam. São "maus funcionários", nesse sentido, cuja repreensão e instrução trará de volta a ordem correta das coisas. Identificando e circunscrevendo o foco do problema, conforme sugere Douglas, circunscrevem-se e controlam-se também suas implicações. Seria interessante acompanhar como se desenrolaria a situação caso estivessem presentes, além de nós três, os padeiros da manhã, aqueles que funcionaram como bodes expiatórios. Por outro lado, eu estava ali, e este talvez seja um ponto importante para a concepção da cena: uma demarcação de posturas e posicionamentos diante do novato. 
O recurso narrativo do "mau funcionário" não aparece apenas nessa situação tensa e desconfortável em que toda uma lógica de relações sociais corre o risco de ser evidenciada e confrontada. Expus anteriormente como a higiene, no Senai, ao mesmo tempo em que se apresenta como um marcador identitário importante para a noção de um padeiro qualificado, passava de algo indiscutível a uma categoria de acusação no momento em que se cruzavam as fronteiras entre a sala de aula e a oficina, entre a teoria e a prática. Embora esse contraste seja particularmente ilustrativo, não seria preciso, na verdade, sair da sala de aula para observar dinâmicas semelhantes, bastando observar como a própria "teoria" sobre as boas práticas de produção se consolida como conteúdo programático do curso.

Como se produzem, afinal, aquelas reações unanimemente enojadas diante da falta de higiene? Certamente não a partir de conceitos como "contaminação direta" e "indireta" que, por si sós, aparecem nas apostilas como uma informação a mais para alunos pouco receptivos a este tipo de conteúdo "teórico". O reflexo de repulsa e a proteção ritual contra a poluição não se dão pela mera inventariação de processos em abstrato, mas afloram fortemente quando ela é incorporada a um sujeito. Se recordarmos os diálogos citados anteriormente, veremos que estão todos estruturados a partir de "maus funcionários", de personagens que, deliberadamente ou não, seguiam procedimentos e costumes errados - o próprio termo "costumes" é sintomático de algo que se quer diminuir em detrimento de uma prática correta e cientificamente apoiada. O colega que não toma banho e fede, o padeiro sujo, de bermuda e chinelo, a vendedora que manipula dinheiro e alimentos. E, de maneira especialmente relevante, aqueles que produziram o clímax da aula: os funcionários que, revoltados com o patrão, urinaram ou colocaram sua carga genética nos alimentos vendidos.

Destaco estes porque permitem uma dupla visualização: por um lado, suas ações sugerem que padrões de higiene podem ser entendidos como "manias do patrão" (ou mesmo como mecanismos de controle deste em relação a seus funcionários), e não como universais, objetivos e impessoais; por outro lado, a maneira como se estruturam as narrativas permite que se perceba que eles estão errados. Estão errados em suas práticas revoltantes e repulsivas, e estão errados também - ou sobretudo - ao sugerir uma vinculação entre limpeza e patrão, entre higiene e relações sociais, ao propor uma parcialidade possível a algo que, "na verdade", é uma questão objetiva e técnica. Nesse processo, o "mau funcionário" aparece como uma contrapartida ao profissional qualificado, que se apropria do reconhecimento da higiene como um "universal", um "certo", e não como uma "mania do patrão", e faz desse reconhecimento um marcador fundamental de sua distinção. ${ }^{18}$ 
Não é apenas na oficina, portanto, que vemos as ideias de limpeza e higiene sendo apropriadas em interações e relações sociais específicas; tampouco o contexto de uma padaria a pleno vapor é o único no qual a higiene aparece como um princípio que atravessa lógicas de ação e sentidos particulares. O próprio ensino da higiene como algo que está além de relações sociais e históricas só se legitima apoiado ele mesmo nessas interações entre pessoas ou personagens específicas. Embrenhada nesse social, de "exemplos" e "contraexemplos", a independência da higiene desenvolve-se como padrão legítimo e unidade de valor; articuladas a essa consolidação da higiene, consolidam-se também as distinções entre o certo e o errado, o trabalhador comum e o profissional qualificado, a qualificação e o aprendizado no próprio ambiente de trabalho. Para além da "sujeira", portanto, está em jogo a própria legitimação de uma determinada configuração de um mercado de trabalho e de posições nesse campo, e é em função disto que se concebe o lugar ritual do "mau funcionário", agente poluidor, mote da produção daquele sentimento compartilhado de nojo, invocado para ser combatido.

\section{Considerações finais}

No que tange às complexas relações que estabelecem entre agências de regulação, produtores e consumidores de alimentos (e não só de alimentos) muitas vezes com consequências sérias para o que se entende por "culturas tradicionais" ou "classes populares" e que afetam de forma importante as produções e as práticas alimentares - as discussões travadas aqui talvez não sejam mais que anedotas etnográficas, incapazes por si sós de encarar "de frente" esse tema. ${ }^{19}$ Por outro lado, acredito que, se pensarmos esse artigo como um breve desvio de rota, o foco proposto pode ajudar a iluminar outras perspectivas da questão, de uma forma que talvez um embate direto, em sua grandeza e urgência, não permita.

Ao estabelecer um diálogo entre os contextos que pesquisei, a formação de padeiros no Senai e o trabalho em padarias, procurei pensar a higiene como algo ao mesmo tempo dotado de uma agência própria, capaz de mobilizar ações de indivíduos submetidos a determinada lógica, e como uma lógica que é ela mesma apropriada por sujeitos particulares em suas interações cotidianas. Ao invés de pensar a partir de uma separação entre ciência e sociedade, discurso e ação, ou entre prática e estrutura, meu plano foi o de trabalhar as articulações em função das quais tudo isso se atualiza e se mobiliza, argumentando que é apenas nesse emaranhado de articula- 
ções que o "universal" e o "objetivo", mas também as relações entre sujeitos específicos podem existir.

Ressalto, nesse sentido, a importância da maneira como me inseri em campo, para além de pesquisador: como aluno, em um caso, e como padeiro, no outro. Essa entrada é importante em função de uma dificuldade específica: como escapar produtivamente à objetivação e à universalização impostas pelas "boas práticas de fabricação"? Como abordar condições de higiene através de entrevistas com donos de padaria, balconistas e padeiros sem colocá-los diante de uma potencial (e perigosa) acusação? É preciso compreender que a higiene é um assunto no qual "ciência" e "moral" se associam de maneira particularmente intrincada, deixando pouco espaço para incursões experimentativas quando se trata de movimentados estabelecimentos comerciais do setor de alimentos.

Dessa forma, entrevistas ou abstrações discursivas se apresentariam engessadas de antemão, incapazes de lidar com a complexidade que o tema revela quando encarado por outras abordagens. ${ }^{20}$ Por um lado, não é concebível nesse meio um discurso sobre a higiene a partir de si próprio a não ser que seja positivo, afirmando as qualidades daquele que fala, ou totalmente idealizado a partir de uma normatividade técnica de manuais de conduta. Uma fala mais interessante aparece quando relacionada a outras padarias ou a outros funcionários, embora por trás dessa maior complexidade aparente o efeito seja o mesmo: a valorização de si, que se produz por contraste. Em ambos os casos a situação está sob controle, se retomarmos as proposições de Douglas com as quais viemos dialogando, dentro de uma ordem concebida ou ao menos com alvos identificados e circunscritos.

Bastante diferentes são as situações vistas neste artigo, que se destacam justamente pelo componente de incerteza que trazem, pela tensão envolvendo os sujeitos que trabalhavam na padaria, bem como as complexas manobras discursivas utilizadas para colocar dentro de uma ordem possível (para o próprio sujeito e para o funcionamento da padaria como um todo) o que de fato ocorria ali. É o caso do conserto da geladeira, mas também das interações e provocações entre alunos e instrutores do Senai, colocados em uma posição ambígua, entre agentes de uma normatividade técnica promovida pela instituição e sujeitos de carne e osso, habitantes de um mundo real. Foi nesse sentido que procurei utilizar a aproximação etnográfica a (e posteriormente entre) esses dois contextos como instrumento de estranhamento. Afinal, explicitar e explorar as contradições de um imaginário ideal me parece uma das maiores potencialidades de se trabalhar a produção de conhecimento etnográfico não apenas através de entrevistas formais ou de abstrações discursivas, mas no contexto da interação com uma fornada 
de pães, um cesto velho, uma geladeira entulhada, uma encomenda, uma conversa informal no corredor de uma escola...

Essa atenção aos detalhes e às concretudes das interações, além de permitir escapar ao engessamento que determinados objetos parecem impor à reflexão, revela-se uma alternativa para evitar algumas das possíveis consequências lógicas de outras abordagens, como o estabelecimento de fronteiras e caracterizações reificantes de conjuntos de pessoas, das relações que estabelecem entre si ("trabalhadores de padarias" e "professores do Senai", "ciência" e "sociedade", ou ainda uma "elite econômica e intelectual" e "classes populares") e das próprias classificações e lógicas que se mobilizam aí. Evitam-se, dessa forma, becos analíticos sem saída como "os padeiros não seguem a higiene tal qual recomendado pelas BPF", "naquela padaria os conhecimentos sobre higiene eram manipulados a seu favor", ou ainda "as classes populares (ou trabalhadoras) comportam-se de tal maneira em relação à higiene", enfatizando, pelo contrário, as capacidades inventivas de apropriação de lógicas e saberes que, embora a princípio distintos, são postos em diálogos e experimentos criativos no curso das interações cotidianas entre diferentes sujeitos.

Com efeito, se há algo que aproxima o Senai e a padaria, em meio a tantos contrastes, é a dinâmica da relação (ressalto: da relação, mais que da diferença) entre um discurso que se apresenta como "oficial" e "racional" sobre a importância da "higiene" - as boas práticas de fabricação, por um lado, e a indignação do patrão, por outro - e a sua apropriação prática pelos sujeitos em suas interações. A impessoalidade se associa ao sujeito, e a poluição surge como ameaça justamente articulada à pureza técnica da assepsia, cuja legitimidade se impõe (ou é evocada pelos sujeitos na dinâmica de negociação da situação) apoiada na ciência e nas Boas Práticas. O que me parece interessante, seja no Senai ou na padaria (e acredito que se possa expandir também para outros contextos em que a questão da regulação sanitária assume contornos e consequências mais sérias), é perceber como a "impessoalidade" e a "objetividade" das "boas práticas de fabricação" não se atualizam senão em função de situações e pessoas específicas, concebendo-se sempre em função de um "outro" (ou mesmo de "outros"). Mais que uma meta ou um objetivo perseguido por si próprio, incessantemente, as noções de higiene aparecem como categorias de acusação articuladas em determinados momentos em que a dinâmica interna é surpreendida, explicitada, ou deseja ser alterada por alguém.

Não é dizer que a higiene e a sujeira são "meras" categorias de acusação, ou que o foco sobre a prática reduz a teoria a palavras vazias e hipócritas, como um "mero" discurso, ou ainda que se insiste naquela velha 
separação cultura e prática, ciência e senso comum. O que quero destacar é que elas são mobilizadas nesse sentido justamente baseadas no reconhecimento da existência e da força de uma instância científica que legitima determinadas práticas como factuais, objetivas e impessoais. Mais que isso, é interessante observar que essa impessoalidade não existe senão quando mobilizada por sujeitos específicos em interações específicas - mesmo quando ainda é apenas uma teoria que se deseja ensinar aos alunos, como vimos. E é justamente seu caráter de categoria "ideal" e "impessoal" que é manipulado, em situações específicas, pelos sujeitos envolvidos, sejam eles um aluno, um diretor, um mecânico, um cliente, o próprio patrão ou uma instituição reguladora.

Recebido em 05/02/2018

Aceito em 05/10/2018

\section{Antônio de Salvo Carriço}

Doutor em Antropologia Social pelo PPGAS/MN/UFRJ, onde desenvolve atualmente atividades de pós-doutorado. É um dos coordenadores do Núcleo de Antropologia do Trabalho, estudos biográficos e de trajetórias (NuAT/PPGAS), grupo de pesquisa em que atua desde sua fundação. E-mail: ancarrico@yahoo.com.br 


\section{Notas}

1 O Serviço Nacional de Aprendizagem Industrial é uma das principais referências no Brasil no que tange ao ensino profissionalizante, bem como a relações entre indústrias, trabalhadores e governos. Criado em 1942 para mediar a formação de mão de obra para as indústrias de base, conta hoje com 797 unidades operacionais, relacionadas a 28 áreas industriais espalhadas por todos os estados do país. A cada ano cerca de 2,3 milhões de pessoas passam por uma das diversas modalidades de cursos ofertados, complementados por serviços como consultoria e assistência a variados setores.

2 Stengers remete a imagem de objetividade da ciência a uma tradição construída a partir de nomes como Humes, Locke, Descartes e Kant, acrescentando a interessante observação de que essa imagem "não teria qualquer pertinência se ela não tivesse encontrado um grande número de protagonistas, pouco interessados na filosofia mas muito interessados nas vantagens da etiqueta de cientificidade fornecida pela semelhança com essa imagem. [...] é seu desdobramento que conta: o cientista transforma-se em representante acreditado de uma conduta em relação à qual toda forma de resistência poderá ser considerada obscurantista ou irracional" (Stengers 2002:31, grifo meu).

3 Nesse sentido, é possível afirmar, seguindo a sugestão de Eriksen (2001) de que a antropologia lida com grandes questões a partir de pequenos lugares, que o artigo busca problematizar, ainda que desde contextos bastantes particulares e de maneira talvez pouco explícita, o espaço cada vez mais central da vigilância sanitária como instituição e/ou argumento que se apresentam como puramente técnicos, concebendo-a, sobretudo, como um instrumento político operante em diversas escalas. De outra perspectiva, deve-se ter em mente também os diálogos entre trabalhos como os de Latour (1993) e Foucault (2008), que remontam, em suas controvérsias, à legitimação da higiene como instituição capaz de exercer poder sobre a vida das pessoas, e como esse processo envolve uma série de disputas, apropriações e associações entre diferentes sujeitos sociais.

4 As localidades exatas serão todas borradas pelo tipo de discussão que trago aqui.

5 http://gcn.net.br/noticias/351331/franca/2017/05/padaria-e-interditada-por-falta-de-higiene-e-risco-a-saude-publica

6 https://g1.globo.com/sao-paulo/sorocaba-jundiai/noticia/com-baratas-e-equipamentos-deteriorados-vigilancia-sanitaria-interdita-padaria-em-sorocaba.ghtml

7 http://g1.globo.com/ro/vilhena-e-cone-sul/noticia/2017/02/vigilancia-acha-insetos-mortos-e-produtos-vencidos-em-padaria-de-ro.html

8 https://oglobo.globo.com/rio/operacao-encontra-farinha-com-fezes-de-rato-em-padaria-na-gavea-21175921 
9 https://g1.globo.com/goias/noticia/padaria-e-interditada-por-ter-rato-baratas-e-alimentos-vencidos-em-goiania.ghtml

10 Subvertendo, em certo sentido, uma concepção do ensino profissionalizante como alinhado automaticamente aos interesses patronais.

11 Por exemplo, o documento "Boas práticas de fabricação (BPF)", divulgado pela Embrapa em seu site (Machado, Dutra \& Pinto 2015).

12 Sobre a categoria novato, ver Carriço (2016a e 2016b).

13 É evidente, por outro lado, que discutir limpeza e sujeira dessa forma apresenta algumas dificuldades. Ainda que esteja consciente que estes são termos que só fazem sentido segundo determinada lógica cultural, e que dizer que algo está limpo ou sujo vai muito além de uma mera constatação, trata-se de contextos que, vistos por outra escala, estão em muitos sentidos próximos de uma experiência compartilhada também por mim (ocidental, urbana, moderna, brasileira e muitos outros marcadores). Deste modo, essas particularidades da maneira como noções de limpeza e sujeira estão inseridas em um complexo simbólico mais amplo se veem profundamente arraigadas e internalizadas, de certa forma encobertas e facilmente naturalizáveis. É preciso, portanto, fazer aquele esforço de "estranhar o familiar" proposto por Velho (1978) e DaMatta (1978), e é nesse sentido que me empenho ao pensar nas maneiras concretas como se apresentam tais princípios de classificação no cotidiano da padaria e do curso.

14 Dassa e Maillard (1996) escrevem a respeito de uma utopia prescritiva, uma tentação irresistível de gerentes, organizadores e formadores que funciona como uma negação da irredutibilidade das práticas à sua conceptualização operatória (:34).

15 Dassa e Maillard (1996) relacionam a exigência de qualidade e boas práticas na produção a novas formas de alienação e controle do funcionário, mas apontam também para essa possibilidade de apropriação das regras pelos próprios trabalhadores em defesa própria.

16 Permitindo-me assim acessar e explorar concepções específicas de trabalho, em especial as ambiguidades que permeavam as fronteiras entre um sentimento de exploração e a valorização do esforço individual diante das dificuldades impostas pela jornada de trabalho. As perturbações causadas pelo pesquisador (Devereux 1980), neste caso, foram um instrumento fundamental para contrapor uma naturalização aparente das condições de trabalho nas padarias e o silêncio com que me deparava a respeito dessas questões.

17 Uso o termo no sentido proposto por autores como Velho (2006) e Hughes (1971), uma "negociação da realidade" que se dá em um nível mais inconsciente, porém ativo, a partir da interação entre sujeitos diante da conformação de determinada estrutura social.

18 Aludindo à ruptura fundamental, apontada por Bachelard (1996), entre a "ciência" e a "não ciência", esta atrelada à "opinião". É interessante também, seguin- 
do Stengers (2002), remeter essa distinção entre o "certo" e a "mania" à oposição entre medicina "racional" e charlatanismo, assim como a observação de que a "não ciência", neste caso, é definida com muito mais ênfase que a própria "ciência".

19 Para uma abordagem mais direta do tema da vigilância sanitária e das relações conflituosas que se estabelecem com produtores e consumidores de alimentos, ver, por exemplo, as controvérsias do caso da fabricação de queijos artesanais de leite cru em Minas Gerais estudado por Cintrão (2016).

20 Trabalhar por meio de entrevistas se revelou, para mim, uma estratégia bastante infrutífera quando tentei dar sequência à pesquisa de mestrado no próprio Senai. A fluidez das conversas durante as aulas se convertia em um interrogatório estéril e duro, com pouquíssimo engajamento dos entrevistados. Sobre esse contraste, ver Carriço (2013). 


\section{Referências bibliográficas}

APPADURAI, Arjun. 2008. "Introdução: mercadorias e a política do valor". In: (org.), A vida social das coisas: as mercadorias sob uma perspectiva cultural. Niterói: Ed. da Universidade Federal Fluminense.

BACHELARD, Gaston. 1996. Formação do espirito cientifico. Rio de Janeiro: Contra-ponto. CARRIÇO, Antônio de Salvo. 2011. Segredos de profissão: notas etnográficas de um aprendiz de padeiro. Dissertação de mestrado em Antropologia Social, UFRJ. Disponível em : http://objdig.ufrj.br/72/teses/757199. pdf. Acesso em 19/12/2018. 2013 "De(s)ilusões biográficas". In: LEITE LOPES, José Sergio; CIOCCARI, Marta (orgs). Narrativas da desigualdade: memórias, trajetórias e conflitos. Rio de Janeiro, Mauad.

2016a Chapa quente: perspectivas etnográficas sobre o trabalho em padarias. Tese de doutorado em Antropologia Social, UFRJ. Disponível em: http://objdig.ufrj. br/72/teses/842712.pdf. Acesso em 19/12/2018.

2016b "Configurações hierárquicas em um balcão de padaria" in: Revista Theomai. Buenos Aires. Disponível em: http://revista-theomai. unq.edu.ar/NUMERO 33/5.\%20Art Carrico.pdf. Acesso em 19/12/2018. no prelo. "'Isso não é pra você': diálogos etnográficos entre o trabalho em padarias e a qualificação profissional. in Ilha - Revista de Antropologia. Florianópolis: UFSC.

CINTRÃO, Rosângela Pezza. 2016. Segurança, qualidade e riscos: a regulação sanitária e os processos de (i)legalização dos queijos artesanais de leite cru em Minas Gerais. Tese de doutorado em Ciências Sociais em Desenvolvimento, Agricultura e Sociedade, UFRRJ.

DAMATTA, Roberto. 1978. "O ofício do etnólogo, ou como ter 'anthropological blues'". In: E. O. Nunes (org.), A aventura sociológica: objetividade, paixão, improviso e método na pesquisa social. Rio de Janeiro: Zahar Editores. pp. 23-35.

DASSA, Sami \& MAILLARD, Dominique. 1996. "Exigences de qualité et nouvelles formes d'alienation". Actes de la recherche en sciences sociales, 115, Juin.

DEVEREUX, Georges. 1980. De l'angoisse à la methode dans les sciences du comportement. Paris: Aubier.

DOUGLAS, Mary. 1966. Purity and Danger. Harmondsworth: Penguin Books. . 1968. "Pollution". In: David L. Sills (ed.), International Encyclopedia of the Social Sciences, v. 12:336-42. New York: Macmillan.

ERIKSEN, Thomas Hylland. 2001. Small Places, Large Issues: An introduction to Social and Cultural Anthropology. London: Pluto Press.

FOUCAULT, Michel. 2008. Nascimento da biopolítica. Curso dado no Collège de France (1978-1979). São Paulo: Martins Fontes.

HUGHES, Everett. 1971. The sociological eye (selected papers). Chicago: Aldine-Atherton.

LATOUR, Bruno. 1993. The pasteurization of France. Cambridgeand London: Harvard University Press. 1994. Jamais fomos modernos: ensaio de antropologia simétrica. Rio de Janeiro: Ed. 34. . 2001. A esperança de Pandora: ensaios sobre a realidade dos estudos científicos. Bauru, SP: Edusc.

LATOUR, Bruno \& WOOLGAR, Steve. 
1997. A vida de laboratório: a produção dos fatos científicos. Rio de Janeiro: Relume Dumará.

LINHART, Robert. 1980. Greve na Fábrica. Rio de Janeiro: Paz e Terra. MACHADO, R.; DUTRA, A. \& PINTO, M. 2015. "Boas práticas de fabricação (BPF)". Embrapa Agroindústria de Alimentos. Documentos, 120. Rio de Janeiro: Embrapa Agroindústria de Alimentos. Disponível em: http:// ainfo.cnptia.embrapa.br/digital/bitstream/item/132846/1/DOC-120.pdf. Acesso em 12/04/2017.

MARX, Karl. 2006. O Capital - crítica da economia política. Livro 1: O Processo de Produção do Capital. 24 ed. Trad. Reginaldo Sant'Anna. Rio de Janeiro: Civilização Brasileira.

ROY, Donald F. 1953. "Work Satisfaction and Social Reward in Quota Achievement: An Analysis of Piecework Incentive". American Sociological
Review, XVIII: 507-514, October. STENGERS, I. 2002. A invenção das ciências. São Paulo: Editora 34.

THOMPSON, E. P. 1998. Costumes em comum. São Paulo: Companhia das Letras.

VELHO, Gilberto. 1978. "Observando o familiar". In: E. O. Nunes (org.), A aventura sociológica: objetividade, paixão, improviso e método na pesquisa social. Rio de Janeiro: Zahar Editores. pp. 36-46.

. 2006. Subjetividade e sociedade: uma experiência de geração. 4 ed. Rio de Janeiro: Jorge Zahar Ed.

WACQUANT, Loïc. 2002. Corpo e alma. Notas etnográficas de um aprendiz de boxe. Rio de Janeiro: Relume Dumará.

WEIL, Simone. 1979. A condição operária e outros escritos sobre a opressão. Rio de Janeiro, Paz e Terra. 


\section{PRÁTICAS DE FABRICAÇÃO: HIGIENE E SUJEIRAS NA PRODUÇÃO DE PÃES E PADEIROS}

\section{Resumo}

Este artigo aborda a relação entre discursos técnicos, construções simbólicas e práticas sociais, problematizando suas fronteiras aparentes e analisando as articulações pelas quais se constituem efetivamente. Esta discussão é mobilizada pela questão da higiene envolvida na produção de pães a partir de dois contextos pesquisados etnograficamente: um curso de formação de padeiros, no Senai, e padarias propriamente ditas. À primeira vista, são contextos opostos neste quesito - o Senai possui instalações que primam pela limpeza e enfatiza essa preocupação nas aulas, enquanto os pães produzidos nas padarias pesquisadas dividiam espaço com roedores, baratas, bactérias e instrumentos deteriorados. Contudo, argumenta-se que ambos podem ser entendidos a partir de dinâmicas semelhantes se a "higiene" for considerada segundo uma lógica de apropriação específica, enfatizando as interações sociais particulares a partir das quais seu caráter "objetivo", "científico" e "impessoal" é mobilizado. Palavras-chave: Higiene, Boas práticas de fabricação, Padarias, Senai, Etnografia.

\section{MANUFACTURING PRACTICES: HYGIENE AND DIRT IN THE MAKING OF BREAD AND BAKERS}

\begin{abstract}
This article discusses the relation between technical discourses, symbolic constructions and social practices, questioning their apparent borders and analyzing the hinges by means of which they effectively constitute themselves. This is explored through the matter of hygiene in the production of bread, in two contexts researched ethnographically: a bakery course offered by SENAI and bakeries themselves. At first glance, these appear to be opposing contexts - the SENAI has facilities that are conspicuous for their cleanliness, and the Institute emphasizes this concern in taught classes; in contrast, the bread produced in the bakeries that I researched vied for space with rodents, roaches, bacteria and damaged instruments. However, it is argued that both can be understood in light of a similar dynamic, so long as "hygiene" is considered within a specific logic of appropriation that emphasizes the particular social interactions from which its "objective", "scientific" and "impersonal" character is mobilized.

Keywords: Hygiene, Good Manufacturing Practices, Bakeries, SENAI, Ethnography
\end{abstract}




\title{
PRÁCTICAS DE FABRICACIÓN: HIGIENE Y SUCIEDADES EN \\ LA PRODUCCIÓN DE PANES Y \\ PANADEROS
}

\begin{abstract}
Resumen
Este artículo aborda la relación entre discursos técnicos, construcciones simbólicas y prácticas sociales, problematizando sus fronteras aparentes y analizando las articulaciones por las cuales se constituyen efectivamente. Esta discusión es movilizada por la cuestión de la higiene que está involucrada en la producción de panes desde dos contextos investigados etnográficamente: un curso de formación de panaderos del SENAI y panaderías comerciales propiamente dichas. A primera vista, son contextos opuestos en este aspecto - el SENAI tiene instalaciones que se destacan por su limpieza y enfatiza esta preocupación en las clases, mientras que los panes producidos en las panaderías investigadas comparten el espacio con roedores, cucarachas, bacterias e instrumentos deteriorados. Sin embargo, se argumenta que ambos pueden ser entendidos desde dinámicas similares si se considera la "higiene" dentro de una lógica de apropiación específica, enfatizándose las interacciones sociales particulares a partir de las cuales su carácter "objetivo", "científico" e "impersonal" es movilizado.
\end{abstract}

Palabras-clave: Higiene, Buenas Prácticas de Fabricación, Panaderías, SENAI, Etnografía. 